\section{A Double-flowered Geraldton Wax (Chamelaucium uncinatum Schauer) with an Anomalous Flower in the Ovary}

\author{
Jen A. McComb \\ School of Biological and Environmental Science, Murdoch University, Murdoch, \\ Western Australia 6150 \\ Chris Newell ${ }^{1}$ and George Lullfitz \\ Lullfitz Nursery, Caporn Street, Wanneroo, Western Australia 6065
}

Additional index words. anomalous flowers, teratology, petaloid staminode, Myrtaceae, homeosis

\begin{abstract}
A naturally occurring mutant of Chamelaucium uncinatum Schauer (Geraldton wax) is described. It has double flowers with the staminodes transformed into petals. Pollen is exuded from the anthers but is not deposited on the pollen presenter in a lipid droplet, which is normal for the species. An anomalous secondary flower with petals, stamens, and gynoecium is present in the ovary.
\end{abstract}

The Australian native shrub Chamelaucium uncinatum is grown as a garden or pot plant for cut flowers. In $1991, \approx 78$ million stems were harvested as cut flowers in Australia and Israel (Considine et al., 1994), and the plant also is grown in California. Considine et al. (1994) and Growns and Considine (1994) described species variation. An unusual double-flowered mutant, which otherwise fits the description of Ecotype no. 4 of Growns and Considine (1994), was found by G.L. in Acacia woodland on secondary sand dunes south of Lancelin (129 km north of Perth, Western Australia). At least two other double-flowered pink or white C. uncinatum are in cultivation, but none has the same abnormality of the ovary as the plant found by G.L. In addition, flowers of the anomalous-flowered plant are larger and have reddish centers, which are not present in the other pink double-flowered line.

\section{Materials and Methods}

The anomalous double-flowered $C$. uncinatum was propagated from tip cuttings, and the anomaly remained stable. It flowers in October, which is late in the season, and has a vase life similar to that of other cultivars. Flowers of wild-type and double-flowered mutant plants were fixed in $3 \%$ gluteraldehyde in $0.025 \mathrm{M}$ phosphate buffer $(\mathrm{pH} 7.2)$, then rinsed in phosphate buffer, dehydrated, infil- trated, and embedded in Paraplas embedding wax. Sections were cut at $10 \mu \mathrm{m}$ and stained with safranin/fast green.
The flowers of the mutant plants are double due to the petaloid development of the staminodes (Fig. 1 A and D). Wild-type, single C. uncinatum flowers have 10 anthers alternating with 10 staminodes (Fig. 1C). When the flower opens, the double variant has pale-pink petals that darken with age. Similarly, the floral disk is greenish-yellow at anthesis and darkens to red-purple. Occasionally, the filaments of the fertile anthers develop petaloid appendages, and the stigma may appear to have petaloid extensions (Fig. 1G).

The anthers exude a small cylinder of pollen at anthesis (Fig. 1I), and hairs of the style are a lipid-free brush at anthesis (Fig. 1F). A few pollen grains may germinate while in this mass. Toward the end of the flowering season, virtually no pollen is produced. In contrast, wild-type $C$. uncinatum has a pollen presenter, and the pollen is deposited onto the style in a drop of lipid before the flower opens (Fig. 1E). Bennett (1992) and Slaytor and Beardsell (1991) reported pollen germination of pollen on the pollen presenter of normal $C$. uncinatum and on the related genus Darwiniafascicularis.

The most unusual feature of the variant

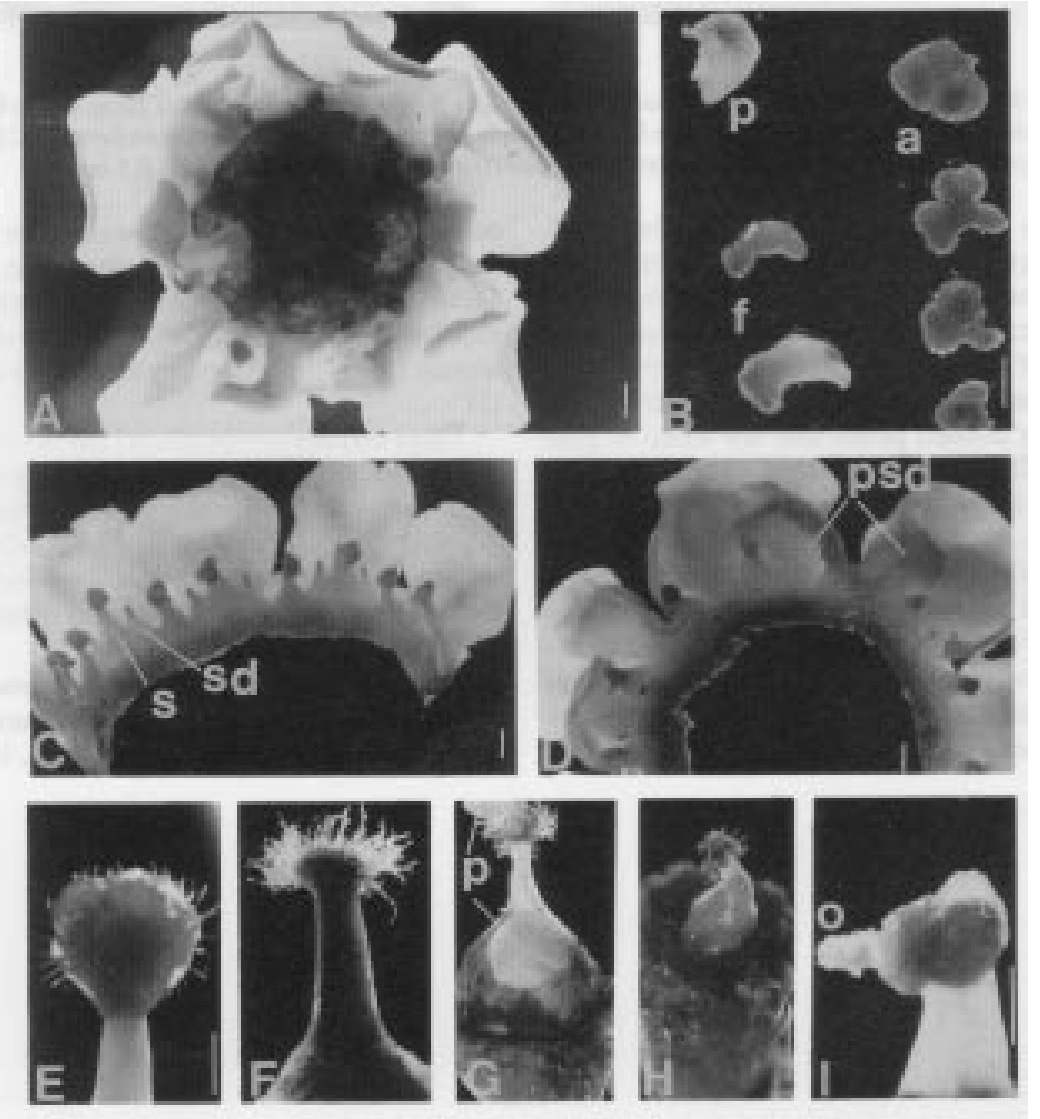

Received for publication 5 Apr. 1995. Accepted for publication 10 Nov. 1995. We thank Gordon Thomson for cutting the sections. The cost of publishing this paper was defrayed in part by the payment of page charges. Under postal regulations, this paper therefore must be hereby marked advertisement solely to indicate this fact.

${ }^{1}$ Current address: Institute of Agriculture, The Univ. of Western Australia, Nedlands, Western Australia 6009

Fig. 1. (A) Double flower of C. uncinatum; (B) structures from an anomalous flower in the ovary of a double flower including a (p) petal, (f) two anther filaments, (a) four anthers; (C) (s) whorl of stamens, (sd) staminodes, and petals from a single flower; (D) whorl of stamens, petals, and (psd) petaloid staminodes from a double flower; (E) pollen presenter of a single flower at anthesis; (F) style and stylar hairs of a double flower at anthesis; (G) ovary of a double flower with the wall partly removed to expose the enclosed petals of the anomalous flower where one (p) petal has extended through the stylar canal and protrudes from the stigma; $(\mathbf{H})$ ovary, style, and stigma of the anomalous flower shown in $\mathrm{G}$ with surrounding petals and stamens removed; and (I) stamen from the upper floral whorl of a double flower with a mass of extruded (o) pollen. For A, C, and D, the bar scale is $1 \mathrm{~mm}$; for B and E to I, the bar scale is $0.5 \mathrm{~mm}$. 


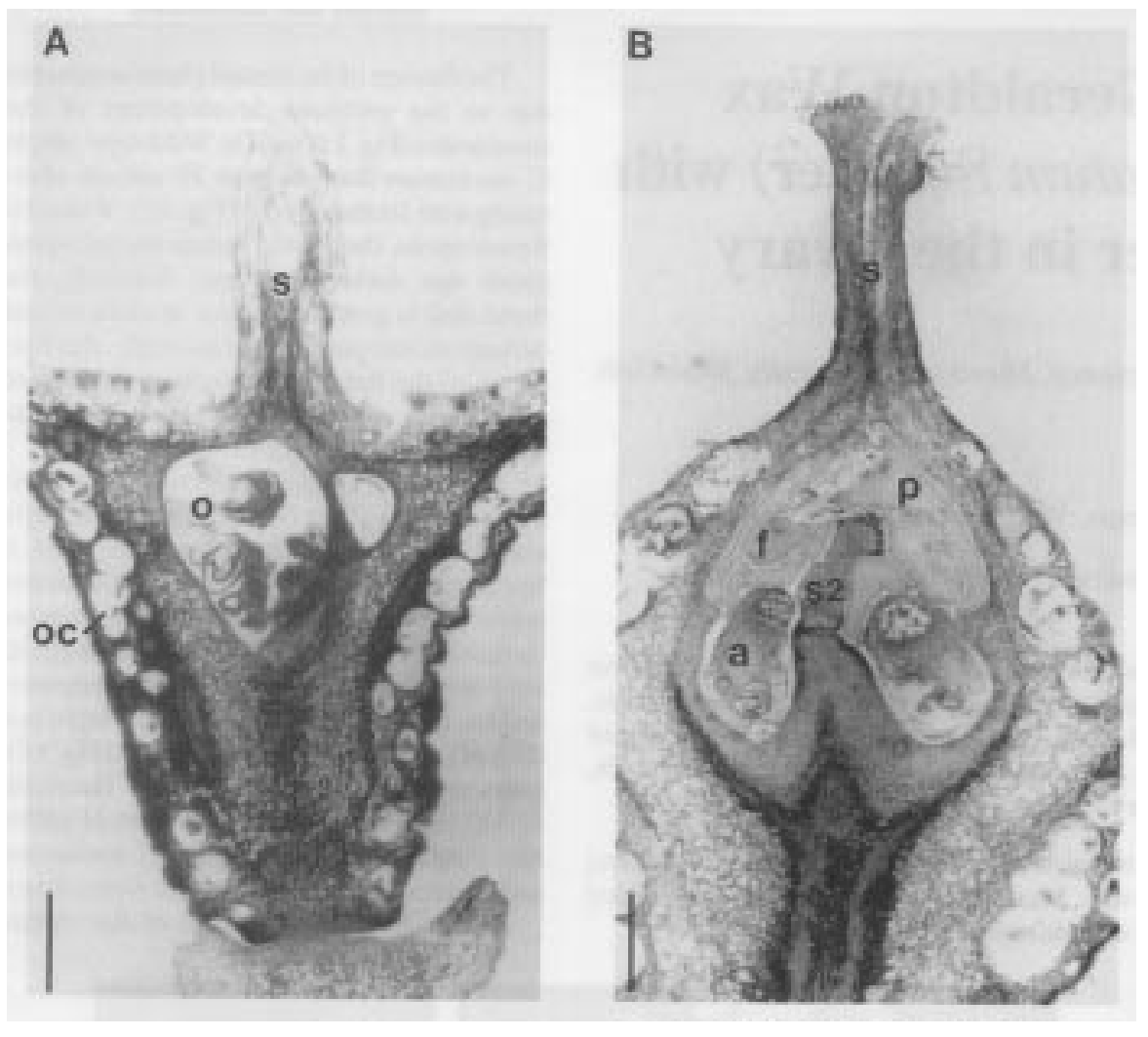

Fig. 2. Sections of Chamelaucium uncinatum flowers. (A) Single flower of a normal plant: (s) style, (o) ovules, and (oc) oil cavity. (B) Double flower: (s) style and structures of the anomalous flower; (s2) style topped with stylar hairs, (p) petals, (a) anther, and (f) anther filament. Bar scale $=0.5 \mathrm{~mm}$.

was in the gynoecium. It is female-sterile, having no ovules, and the ovary is partly filled with parenchyma cells. In the ovary, there is an ectopically developed flower that causes the base of the style to appear swollen (Figs. $1 \mathrm{~B}$ and $\mathrm{G}$ and $2 \mathrm{~B}$ ). This anomalous flower has two to four hooded petals that are white or pale pink. The petals may extend, push through the stylar canal, and protrude from the stigma, giving the appearance of a petaloid stigma (Fig. 1G). The style may be split by the expansion of the anomalous flower, which then is visible in the center of the flower. The anomalous flower also has two to four stamens with some mature pollen. The stamen walls have endothecial thickenings and a gland. In the
McComb, 1969; Meyer, 1966). The nature of the genetic and physiological control of the development of floral whorls is known in some detail (Meyerowitz, 1994; Okamuro et al., 1993). The development of the anomalous flower in the ovary is probably due to failure of the floral apex to terminate growth after differentiation of the carpels. There are few examples of this type of anomaly, but in Arabidopsis, mutants are known in which the floral apex reverts to an inflorescence meristem inside the ovary, causing the ovary to split open as an ectopic inflorescence grows out (Okamuro et al., 1993).

The showiness of this Geraldton wax mutant makes it a valuable addition to the commercially available cultivars, apart from its interest for developmental studies.

\section{Literature Cited}

Acquaah, G., J.W. Saunders, and L.C. Ewart. 1992. Homeotic floral mutations. Plant Breeding Rev. 9:63-99.

Bennett, B.R. 1992. Pollen production and presentation in Darwinia fascicularis Rudge. Honours Diss., Univ. of Sydney, Sydney.

Considine. J.A., L. Egerton-Warburton, D. Growns, and A. Fuss. 1994. Preliminary comparison of Chamelaucium uncinatum (Geraldton wax) genetic resources, p. 10.17-10.20. Natl. Wkshp. Austral. Native Flowers, 8-10Feb. 1994, Gatton, Australia.

Growns, D.J. and J.A. Considine. 1994. Ecology and physiology of Chamelaucium uncinatum Schauer genetic resources in situ, p. 5.23-5.26. Natl. Wkshp. Austral. Native Flowers, 8-10 Feb. 1994, Gatton, Australia.

McComb, J.A. 1969. The genetic basis of unisexuality in Isotoma fluviatilis. Austral. J. Bot. 17:514-526.

Metcalf, L.J. 1972. The cultivation of New Zealand trees and shrubs. Reed, Wellington, New Zealand.

Meyer, V.G. 1966. Flower abnormalities. Bot. Rev. 32:165-218.

Meyerowitz, E.M. 1994. The genetics of flower development. Scientific Amer. 271(5):56-65.

Okamuro, J.K., B.G.W. den Boer, and K.D. Jofuku. 1993. Regulation of Arabidopsis flower development. Plant Cell 5:1183-1193.

Slayter, A.T. and D.V. Beardsell. 1991. Secondary pollen presentation in the Chamelaucium alliance of the Myrtaceae: A compact sub-stigmatic ring in Chamelaucium. Austral. J. Bot. 39:229-239. 